\title{
HUBUNGAN ANTARA KECERDASAN EMOSI DENGAN KINERJA GURU MTS ATTAQWA KOTA TANGERANG
}

\author{
Shofi Shofuroh, Bambang S. Arifin \& Irfan Fahmi \\ Fakultas Psikologi UIN Sunan Gunung Djati Bandung, J1. A.H Nasution No. 105 Bandung \\ email: irfanfahmi@gmail.com
}

\begin{abstract}
Abstrak
Penelitian ini berawal dari fenomena adanya guru yang belum dapat menunaikan tugastugasnya secara maksimal dan belum menyelenggarakan PBM secara efesien, efektif dan tepat sasaran. Hal tersebut diduga salah satunya berhubungan dengan kecerdasan emosional yang dimilikinya. Secara umum yang dimaksud dengan kecerdasan emosional dalam penelitian ini adalah kemampuan yang dimiliki oleh seorang individu dalam mengenali emosi diri, mengelola emosi, memotivasi diri, empati dan keterampilan dalam membina hubungan. Berbagai aspek dalam kecerdasan emosional ini diduga berhubungan dengan kinerja yang ditampilkannya. Populasi yang akan dijadikan sebagai subjek penelitian adalah dewan guru MTs At Taqwa Kota Tangerang yang tercatat dan aktif mengikuti proses belajar mengajar. Metoda penelitian yang digunakan adalah metoda penelitian kuantitatif. Sedangkan analisis yang digunakan adalah analisis korelasional. Dikarenakan jumlah populasi penelitian kurang dari 100 orang, maka seluruh populasi dijadikan sebagai subjek penelitian. Hasil analisis data memperlihatkan bahwa $t_{\text {hitung }}$ lebih besar daripada $\mathrm{t}_{\text {tabel }}$. Hal ini memiliki arti bahwa $\mathrm{H}_{0}$ ditolak dan $\mathrm{H}_{1}$ diterima, sehingga dapat dikatakan bahwa terdapat hubungan positif antara kecerdasan emosional dengan kinerja guru MTs At Taqwa Kota tangerang.
\end{abstract}

Kata kunci: kecerdasan emosi, kinerja, guru

\begin{abstract}
This research based on the phenomena that some teachers have not done their job effectively and efficiently. It is expected that emotional intelegence has correlation with that phenomena. Emotional intelegence is an individual ability to know their own emotion, manage the emotion, motivate themselves, have emphaty and skill in relationship. Some aspects in emotional intelegence expected have correlation with performance. Population are teachers MTs At Taqwa Tangerang who are actively doing the teaching and learning process. This research used quantitative methodology with correlational analysis. Subjects are 100 teachers. Result shows that $t_{\text {hitung }}$ is more than $t_{\text {tabel }}$. Therefore, $H_{0}$ is not accepted and $H_{1}$ is accepted so that there is positive correlation between emotional intelegence and teachers performance at MTs At Taqwa Tangerang.
\end{abstract}

Keywords : emotional intelegence, performance, teacher

\section{PENDAHULUAN}

Pendidikan pada hakikatnya adalah usaha membudayakan manusia atau memanusiakan manusia, pendidikan amat strategis untuk mencerdaskan kehidupan bangsa dan diperlu- kan guna meningkatkan mutu bangsa secara menyeluruh. Pendidikan adalah usaha sadar dan terencana untuk mewujudkan suasana belajar dan proses pembelajaran agar peserta didik secara aktif mengembangkan potensi dirinya untuk memiliki kekuatan spiritual keaga- 
maan, pengendalian diri, kepribadian, kecerdasan, akhlak mulia, serta keterampilan yang diperlukan dirinya, masyarakat, bangsa dan negara.

Penyelenggaraan pendidikan di Indonesia merupakan suatu sistem pendidikan nasional yang diatur secara sistematis. Pendidikan nasional berfungsi mengembangkan kemampuan dan membentuk watak serta peradaban bangsa yang bermartabat dalam rangka mencerdaskan kehidupan bangsa, bertujuan untuk berkembangnya potensi peserta didik agar menjadi manusia yang beriman dan bertakwa kepada Tuhan Yang Maha Esa, berakhlak mulia, sehat, berilmu, cakap, kreatif, mandiri, dan menjadi warga negara yang demokratis serta bertanggung jawab (UU No. 20 Tahun 2003).

Fungsi pendidikan harus betul-betul diperhatikan dalam rangka mencapai tujuan pendidikan nasional sebab tujuan berfungsi sebagai pemberi arah yang jelas terhadap kegiatan penyelenggaraan pendidikan sehingga penyelenggaraan pendidikan seharusnya: 1) diselenggarakan secara demokratis dan berkeadilan serta tidak diskriminatif dengan menjunjung tinggi hak asasi manusia, nilai keagamaan, nilai kultural, dan kemajemukan bangsa, 2) pendidikan diselenggarakan sebagai satu kesatuan yang sistemik dengan sistem terbuka dan multimakna, 3) pendidikan diselenggarakan sebagai suatu proses pembudayaan dan pemberdayaan peserta didik yang berlangsung sepanjang hayat, 4) pendidikan diselenggarakan dengan memberi keteladanan, membangun kemauan, dan mengembangkan kreativitas peserta didik dalam proses pembelajaran, 5) pendidikan diselenggarakan dengan mengembangkan budaya membaca, menulis, dan berhitung bagi segenap warga masyarakat, 6) pendidikan diselenggarakan dengan memberdayakan semua komponen masyarakat melalui peran serta dalam penyelenggaraan dan pengendalian mutu layanan pendidikan.

Peningkatan mutu pendidikan ditentukan oleh kesiapan sumber daya manusia yang terlibat dalam proses pendidikan. Guru merupakan salah satu faktor penentu tinggi rendahnya mutu hasil pendidikan mempunyai posisi strategis maka setiap usaha peningkatan mutu pendidikan perlu memberikan perhatian besar kepada peningkatan guru baik dalam segi jumlah maupun mutunya. Keberhasilan penyelenggaraan pendidikan sangat ditentukan kesiapan guru dalam mempersiapkan peserta didiknya melalui kegiatan belajar mengajar. Namun demikian posisi strategis guru untuk meningkatkan mutu hasil pendidikan sangat dipengaruhi oleh kemampuan profesional guru dan mutu kinerjanya.

Guru dituntut memiliki kinerja yang mampu memberikan dan merealisasikan harapan dan keinginan semua pihak terutama masyarakat umum yang telah mempercayai sekolah dan guru dalam membina anak didik. Dalam meraih mutu pendidikan yang baik sangat dipengaruhi oleh kinerja guru dalam melaksanakan tugasnya sehingga kinerja guru menjadi tuntutan penting untuk mencapai keberhasilan pendidikan. Secara umum mutu pendidikan yang baik menjadi tolok ukur bagi keberhasilan kinerja yang ditunjukkan guru.

Guru pada prinsipnya memiliki potensi yang cukup tinggi untuk berkreasi guna meningkatkan kinerjanya. Namun potensi yang di-miliki guru untuk berkreasi sebagai upaya meningkatkan kinerjanya tidak selalu berkembang secara wajar dan lancar disebabkan adanya pengaruh dari berbagai faktor baik yang muncul dalam pribadi guru itu sendiri maupun yang terdapat di luar pribadi guru.

Seperti yang terjadi di MTs At Taqwa misalnya. Berdasarkan evaluasi yang dilakukan oleh Yayasan Perguruan Islam At Taqwa pada tahun ajaran 2008-2009 diperoleh data bahwa sekitar 40\% guru MTs At Taqwa belum dapat menunaikan tugas-tugasnya secara maksimal. Beberapa indikator dari hal tersebut adalah dari segi administrasi sebanyak $25 \%$ guru tidak memiliki silabus dan Rencana Persiapan Pembelajaran (RPP), tidak membuat program tahunan dan program semester, serta tidak membuat laporan hasil ulangan harian secara rutin kepada kepala madrasah. Dari segi kedisiplinan sebanyak 5\% guru masuk dan keluar kelas tidak sesuai dengan waktu yang ditentukan. Serta dari segi inovasi sebanyak $10 \%$ guru tidak mempunyai program remedial untuk siswa yang belum mencapai standar kriteria ketuntasan minimal (KKM), tidak mempunyai program pengayaan bagi siswa yang telah mencapai standar KKM serta tidak melakukan analisa terhadap hasil evaluasi atau ulangan.

Kenyataan tersebut sangat memprihatinkan dan mengundang berbagai pertanyaan tentang kompetensi guru MTs At Taqwa terhadap profesinya. Di sisi lain kinerja guru MTs At Taqwa pun dipersoalkan ketika memperbincangkan masalah peningkatan mutu pendidi- 
kan di MTs At Taqwa di tengah-tengah persaingan dengan sekolah negeri di Kota Tangerang.

Ketimpangan antara kondisi ideal yang harus dijalani guru sesuai harapan Undang-undang tentang Sistem Pendidikan Nasional No. 20 Tahun 2003 dengan kenyataan yang terjadi dilapangan merupakan suatu hal yang perlu dan patut untuk dicermati secara mendalam tentang faktor penyebab munculnya persoalan tersebut, sebab hanya dengan memahami faktor yang berpengaruh terhadap kinerja guru maka dapat dicarikan alternatif pemecahannya sehingga faktor tersebut bukan menjadi hambatan bagi peningkatan kinerja guru melainkan mampu meningkatkan dan mendorong kinerja guru ke arah yang lebih baik sebab kinerja sebagai suatu sikap dan perilaku dapat berubah dari waktu ke waktu.

Menurut Subroto (1997: 3), yang dimaksud dengan kinerja guru dalam proses belajar mengajar adalah kesanggupan atau kecakapan para guru dalam menciptakan suasana komunikasi yang edukatif antara guru dan peserta didik yang mencakup suasana kognitif, afektif dan psikomotorik sebagai upaya mempelajari sesuatu berdasarkan perencanaan sampai dengan tahap evaluasi dan tindak lanjut agar mencapai tujuan pengajaran.

Kinerja guru juga dapat diartikan sebagai prestasi kerja guru untuk meraih prestasi antara lain ditentukan oleh kemampuan dan usaha. Prestasi kerja guru dapat dilihat dari seberapa jauh guru tersebut telah menyelesaikan tugasnya dalam mengajar dibandingkan dengan standar-standar pekerjaan. Kemudian kinerja guru dapat diartikan pula sebagai suatu pencapaian tujuan dari guru itu sendiri maupun tujuan pendidikan dan pengajaran dari sekolah di tempat guru tersebut mengajar.

Berdasarkan pengertian tersebut dapat disimpulkan bahwa kinerja adalah kemampuan kerja seseorang yang diwujudkan dalam tingkah laku yang ditampilkan. Apresiasi pemahaman serta kemampuan bertingkah laku sesuai harapan dapat diidentifikasikan sebagai faktor kerja, kemampuan kerja yang tinggi atau rendah dapat terlihat dari apa yang telah dicapai dan prestasi yang diperoleh dalam suatu pekerjaan.

Dengan demikian yang dimaksud dengan kinerja guru dalam skripsi ini adalah sebagai keberhasilan guru dalam melaksanakan kegiatan belajar mengajar yang bermutu, me- liputi aspek: kesetiaan dan komitmen yang tinggi pada tugas mengajar, menguasai dan mengembangkan metode, menguasai bahan pelajaran dan menggunakan sumber belajar, bertanggung jawab memantau hasil belajar mengajar, kedisiplinan dalam mengajar dan tugas lainnya, kreativitas dalam melaksanakan pengajaran, melakukan interaksi dengan murid untuk menimbulkan motivasi, kepribadian yang baik, jujur dan obyektif dalam membimbing siswa, mampu berfikir sistematis tentang apa yang dilakukannya, dan pemahaman dalam administrasi pengajaran.

Mitchel (1978) memandang bahwa kinerja atau performance merupakan hasil interaksi atau berfungsinya unsur-unsur motivasi, kemampuan, dan persepsi pada diri seseorang. Ia merinci cakupan wilayah kinerja atas lima faktor dominan, yakni a) kualitas kerja, b) kecepatan dan ketepatan, c) inisiatif, d) kemampuan, dan e) komunikasi. Sementara menurut Tollah (1993:78), terdapat tiga kriteria dasar yang berkaitan dengan kinerja guru, yaitu : 1) proses, 2) karakteristik-karakteristik guru, dan 3) hasil atau produk yaitu perubahan sikap siswa.

Terdapat beberapa faktor yang dapat mempengaruhi kinerja guru, salah satu faktornya adalah kecerdasan emosional. Goleman (dalam T. Hermaya, 2007: 58-59), mengemukakan bahwa kecerdasan emosional menentukan posisi seseorang mempelajari keterampilan-keterampilan praktis yang didasarkan pada lima unsurnya yaitu: mengenali emosi diri (kesadaran diri), mengelola emosi, memotivasi diri, mengenali emosi orang (empati) lain dan keterampilan dalam membina hubungan.

Stein dan E. Book, (2002: 32), mengatakan Istilah Emotional Intelligence diciptakan dan secara resmi didefinisikan oleh John Mayer dan Peter Salovey pada tahun 1990. Sementara Reuven Bar-On menyumbangkan ungkapan Emotional Intelligence. Kecerdasan emosi merupakan wacana baru di wilayah psikologi dan pedagogik setelah bertahun-tahun masyarakat sangat meyakini bahwa faktor penentu keberhasilan hidup seseorang adalah IQ. Temuan penelitian di bidang psikologi yang dilakukan oleh Gardner tentang multiple intellegence yang menyatakan bahwa manusia memiliki banyak kecerdasan, yang bukan hanya kecerdasan intelektual saja telah membuka cakrawala baru tentang potensi manusia yang 
belum dieksplorasi untuk mendorong keberhasilan hidup.

Beberapa ahli mencoba merumuskan definisi dari kecerdasan emosional. Diantaranya Rahman (2002: 157-158), yang menyebutkan bahwa kecerdasan emosional adalah metability yang menentukan seberapa baik manusia mampu menggunakan keterampilan-keterampilan lain yang dimilikinya, termasuk intelektual yang belum terasah. Januarisari dan Murtanto, (2002: 157-158), mengemukakan bahwa kecerdasan emosional adalah serangkaian kemampuan, kompetensi dan kecakapan non-kognitif, yang mempengaruhi kemampuan seseorang untuk berhasil mengatasi tuntutan dan tekanan lingkungan.

Dua definisi tentang kecerdasan emosional yang dikemukakan oleh Januarisari dan Murtanto tersebut terlihat kesan penekanan pada hasil yang didapat oleh individu jika menggunakan kemampuan emosionalnya secara optimal. Stein \& Book mengemukakan bahwa kecerdasan emosional adalah kemampuan untuk mengenali perasaan, meraih dan membangkitkan perasaan untuk membantu fikiran, memahami perasaan dan maknanya serta mengendalikan perasaan secara mendalam sehingga membantu perkembangan emosi dan intelektual.

Nggermanto, (2002: 98), mengatakan bahwa kecerdasan emosional adalah kemampuan untuk mengenali perasaan kita sendiri dan perasaan orang lain, kemampuan memotivasi diri sendiri dan kemampuan mengelola emosi dengan baik pada diri sendiri dan dalam hubungan dengan orang lain. Goleman (1997: 57-59) membagi ciri-ciri kecerdasan emosional kedalam lima bagian utama yaitu:

Mengenali Emosi Diri. Mengenali emosi diri adalah merupakan suatu kesadaran diri, mengenali perasaan sewaktu perasaan itu terjadi, kemampuan memantau perasaan dari waktu kewaktu. Mengenali diri adalah merupakan inti kecerdasan emosional yaitu kesadaran akan perasaan diri sendiri sewaktu perasaan timbul. Para ahli psikologi menggunakan istilah yang agak rumit yaitu meta kognisi untuk menyebut kesadaran tentang proses berfikir, dan metamood untuk menyebutkan kesadaran seseorang akan emosi diri sendiri.

Ciri kesadaran diri ini mirip dengan yang disebut oleh Freud sebagai "perhatian tak memihak", dan yang disarankannya bagi mereka yang melakukan psikoanalis (dalam Gole- man, 1997: 63). Perhatian semacam ini memandang kejadian apa pun melalui kesadaran yang netral, sebagai saksi yang berminat namun tidak bereaksi.

Kesadaran diri bukanlah perhatian yang larut kedalam emosi, bereaksi secara berlebihan dan melebih-lebihkan apa yang diserap. Kesadaran diri lebih merupakan modus netral yang mempertahankan refleksi diri bahkan ditengah badai emosi.

Menurut Mayer (dalam Goleman 1997: 64) kesadaran diri berarti waspada baik terhadap suasana hati maupun pikiran tentang suasana hati. Mayer mengemukakan bahwa orang cenderung menganut gaya-gaya khas dalam menangani dan mengatasi emosi dirinya seperti sadar diri, tenggelam dalam permasalahan, dan pasrah.

Mengelola Emosi. Mengelola emosi adalah suatu kemampuan untuk menangani perasaan agar perasaan dapat terungkap dengan tepat. Mengelola emosi berarti penguasaan diri dan kemampuan untuk menghadapi badai emosional yang dibawa sang nasib, dan bukannya menjadi budak nafsu. Dalam Yunani kemampuan ini adalah disebut "sophrosyne", hati-hati, cerdas dalam kehidupan, kebijaksanaan dan keseimbangan yang terkendali.

Menurut Aristoteles (dalam Goleman 1997: 78) kemampuan mengelola emosi adalah kemampuan menyelaraskan antara perasaan dan lingkungan. Menjaga agar emosi yang merisaukan tetap terkendali merupakan kunci menuju kesejahteraan emosi. Apabila emosi terlalu ditekan, terciptalah kebosanan dan jarak, apabila emosi tak terkendali, terlampau ekstrem dan terus menerus, emosi akan menjadi sumber penyakit, seperti depresi berat, cemas, amarah berlebihan, dan gangguan emosional.

Menurut Goleman (1997;78) inti dari mengelola emosi adalah bukan menjauhi perasaan tak menyenangkan agar selalu bahagia, namun tidak membiarkan perasaan menderita berlangsung tak terkendali sehingga menghapus suasana hati yang menyenangkan.

Memotivasi Diri Sendiri. Memotivasi diri sendiri adalah suatu kekuatan emosional yang mampu mengalahkan dan melumpuhkan otak nalar. Murid-murid yang cemas, marah atau depresi akan mengalami kesulitan belajar, orang-orang yang terjebak dalam keadaan-keadaan ini juga menemui kesukaran menyerap informasi yang efisien atau menanganinya dengan baik. 
Bila emosi mengalahkan konsentrasi, yang dilumpuhkan adalah kemampuan mental yang oleh ilmuwan kognitif disebut ingatan kerja, yaitu kemampuan menyimpan dalam benak semua informasi yang relevan dengan tugas yang sedang dihadapi. Perasaan, antusias, gairah, dan keyakinan diri dalam mencapai prestasi adalah karakter pribadi yang cerdas emosinya. Perasaan-perasaan nyaman dari emosi yang dimiliki seseorang dapat membangkitkan motivasi yang tinggi untuk meraih prestasi. Sesuatu yang membuat teristimewanya orang yang cerdas emosinya adalah tingkat ketahanan, ketekunan, antusias dan kegigihan menghadapi tantangan.

Mengenali Emosi Orang Lain (Empati). Mengenali emosi orang lain atau empati dibangun berdasarkan kesadaran-kesadaran diri, semakin terbuka seseorang kepada emosi diri sendiri, maka semakin terampil membaca perasaan orang lain. Kemampuan berempati adalah kemampuan untuk mengetahui bagaimana perasaan orang lain, ikut berperan dalam pergulatan dalam arena kehidupan.

Emosi sangat jarang diungkapkan melalui kata-kata, emosi jauh lebih banyak diungkapkan melalui isyarat. Kunci untuk memahami perasaan orang lain adalah mampu membaca pesan non verbal, seperti nada bicara, gerak-gerik, ekpresi wajah, dan sebagainya. Manfaat dari kemampuan membaca pesan non verbal adalah pandai menyesuaikan diri secara emosional, lebih popular, lebih mudah bergaul, dan mungkin tak mengherankan kalau lebih peka. Dan empati adalah kunci untuk memahami pesan nonverbal.

Membina Hubungan dengan Orang Lain. Kemampuan ini merupakan keterampilan yang menunjang popularitas, kepemimpinan, dan keberhasilan antar pribadi. Mampu menangani emosi orang lain adalah merupakan inti seni membina hubungan. Untuk dapat memanifestasikan kemampuan antar pribadi seseorang harus mencapai tingkat pengendalian diri tertentu, yaitu kemampuan untuk menyimpan kemarahan serta beban stress, dorongan hati dan kegairahannya.

Penyesuaian dengan kebutuhan orang lain membutuhkan sedikit ketenangan dalam diri seseorang. Menangani emosi orang lain merupakan seni yang mantap untuk menjalin hubungan dan membutuhkan kematangan dua keterampilan yaitu manajemen diri dan empati. Dengan landasan ini keterampilan berhubung- an dengan orang lain akan matang. Ini merupakan kecakapan sosial yang mendukung keberhasilan dalam pergaulan dengan orang lain, tidak dimilikinya kerampilan ini akan membawa pada ketidakcakapan dalam dunia sosial atau berulangnya bencana antar pribadi.

Senada dengan pendapat tersebut, Shapira (2001: 5), juga menyebutkan kualitas kecerdasan emosional, diantaranya: empati, mengungkapkan dan memahami perasaan, mengendalikan amarah, kemandirian, kemampuan menyesuaikan diri, disukai, kemampuan memecahkan masalah antarpribadi, ketekunan, kesetiakawanan, keramahan, dan sikap hormat.

Ketika berbicara mengenai urgensitas kecerdasan emosional yang dimiliki seseorang dalam kehidupan, Suharsono (2004: 97), mengungkapkan beberapa keuntungan kecerdasan emosional sebagai berikut; pertama, kecerdasan emosional jelas mampu menjadi alat untuk pengendalian diri, sehingga seseorang tidak terjerumus ke dalam tindakan-tindakan bodoh yang merugikan dirinya sendiri maupun orang lain. Kedua, kecerdasan emosional bisa diimplementasikan sebagai cara yang sangat baik untuk memasarkan atau membesarkan ide, konsep atau bahkan sebuah produk. Ketiga, kecerdasan emosional adalah modal penting bagi seseorang untuk mengembangkan bakat kepemimpinan dalam bidang apa pun. Karena setiap model kepemimpinan sesungguhnya membutuhkan visi, misi, konsep, program dan yang tak kalah pentingnya adalah dukungan dan partisipasi dari para anggota.

Dari beberapa defenisi para ahli tersebut dapat ditarik kesimpulan bahwa kecerdasan emosional adalah suatu kemampuan yang dimiliki oleh individu untuk dapat menggunakan perasaannya secara optimal guna mengenali dirinya sendiri dan lingkungan sekitarnya. Kecerdasan emosional yang dimaksudkan oleh peneliti adalah kemampuan individu untuk mengenali perasaannya sehingga dapat mengatur dirinya sendiri dan menimbulkan motivasi dalam dirinya untuk meningkatkan kualitas hidupnya.

Tidak semua guru MTs At Taqwa menunjukkan kinerja yang tidak maksimal, tetapi masih banyak guru yang memiliki kinerja yang baik. Berdasarkan catatan harian kepala madrasah diketahui beberapa indikator yang ditunjukkan para guru misalnya, saling memberikan informasi diantara sesama guru mengenai peningkatan mutu pembelajaran, menciptakan ik- 
lim yang kondusif saat kegiatan pembelajaran berlangsung, bersedia menerima saran dan kritik untuk kemajuan madrasah, melakukan pertemuan dengan orang tua atau wali murid, membantu siswa yang tak mampu selama siswa tersebut belajar di MTs At Taqwa memberikan bimbingan kepada siswa yang belum dapat membaca al Qur'an, memberikan penghargaan kepada guru dan siswa yang berprestasi, memanggil orang tua ketika anaknya bermasalah, menjalin kerja sama dengan masyarakat sekitar demi tegaknya disiplin madrasah, bahkan ada guru yang membiayai siswa sampai ke perguruan tinggi.

Berbagai hal tersebut menunjukkan tingkat kematangan emosional para guru. Kematangan emosi tersebut juga didukung dengan adanya hubungan harmonis yang terjalin antara guru dengan guru, guru dengan siswa, guru dengan orang tua atau wali murid, guru dengan kepala madrasah dan guru dengan lingkungan sekitar.

Perilaku pendidik yang sering mengabaikan tanggung jawab dan melalaikan tugas maupun fungsinya dalam kerja-kerja pendidikan menjadi indikasi nyata ketidak-matangan emosi. Sebaliknya para guru yang menyadari tugas dan fungsi pokoknya sebagai pendidikan menjadi tanda nyata, bahwa mereka memiliki kecerdasan emosi, sebab seperti yang diungkapkan oleh Jhon Gottman (2001: 14), ketidakmatangan emosi dalam kerja-kerja pendidikan dapat menyebabkan orang lain di sekitarnya terganggu dalam menggunakan keahliannya. Makin kompleks pekerjaan makin penting kecerdasan emosi yang diperlukan.

Fenomena yang terjadi pada kinerja guru-guru MTs At Taqwa Kota Tangerang mengindikasikan karakter yang dikemukakan oleh Goleman tersebut. Sebab sebagai salah satu sekolah tingkat menengah agama yang cukup favorit di Kota Tangerang, MTs At Taqwa menerapkan berbagai kebijakan demi menjaga reputasinya di tengah masyarakat Tangerang. Salah satu kebijakan yang dikeluarkan untuk meningkatkan kinerja guru-gurunya adalah berkaitan dengan proses seleksi. Kriteria penerimaan guru tidak hanya mempertimbangkan kualifikasi keguruan dan penguasaan didaktik metodik yang dibuktikan melalui ijazah, nilai IPK maupun lamanya pengalaman mengajar, namun juga dari hasil interview dilihat secara langsung kematangan emosi para calon guru tersebut sehingga ketika dinyatakan lolos se- leksi, maka diharapkan guru-guru tersebut dapat menjalin komunikasi, memiliki sikap empati yang baik dan dapat menjadi teladan bagi lingkungan pendidikan di MTs At Taqwa.

Meningkatnya kinerja guru dari waktu ke waktu menjadi program prioritas yang diharapkan oleh pimpinan MTs At Taqwa. Salah satu tindakan konkret yang dilakukan adalah diadakannya berbagai pelatihan tentang peningkatan kualitas dan kinerja guru, misalnya pelatihan tentang pencapaian prestasi dan meningkatkan motivasi (Achievement Motivation Training) dan Emotional Spiritual Training (ESQ). Kegiatan tersebut hampir setiap tahun dilaksanakan, baik untuk guru maupun bagi masyarakat profesional dan dilaksanakan di lingkungan MTs At Taqwa. Maka tidak mengherankan apabila MTs At Taqwa menjadi rujukan dan model percontohan bagi sekolahsekolah swasta berbasis agama di Kota Tangerang dalam kaitannya dengan peningkatan etos kerja atau kinerja guru. Meskipun demikian tidak semua guru yang mengikuti pelatihan yang diselenggarakan pihak sekolah terutama yang berhubungan dengan kecerdasan emosional, mampu menunjukkan kinerja yang optimal.

Lanawati Sri (1999: 24) menyebutkan, bahwa kinerja guru atau prestasi kerja adalah hasil yang dicapai oleh guru dalam melaksanakan tugas-tugas yang diembankan kepadanya berdasarkan atas kecakapan, pengalaman dan kesungguhan serta waktu dengan output yang dihasilkan tercermin baik kuantitas maupun kualitasnya. Sebab keberhasilan pendidikan amat bergantung dengan kinerja guru, dan kinerja guru mutlak memerlukan kematangan emosi. Kecerdasan emosi sangat dibutuhkan dalam berinteraksi dengan anak didik, teman sejawat seama guru, atasan di sekolah, bahkan dengan orang tua siswa. Saat guru berinteraksi sangat dibutuhkan sikap empati, mampu mengenali emosi diri dan emosi orang lain, sehingga akan terjalin hubungan saling percaya dan saling membantu antara guru dengan siswa, guru dengan orang tua siswa, guru dengan atasan di sekolah, guru dengan teman sejawat sesama guru yang lainnya. Sikap-sikap tersebut menurut Goleman (2003) merupakan aspek dari kecerdasan emosi.

Dalam melaksanakan tugasnya membentuk lulusan berkompetensi hendaknya guru memiliki Emotional Quotient (EQ) yaitu suatu kemampuan yang dimiliki oleh individu untuk dapat menggunakan perasaannya secara opti- 
mal guna mengenali dirinya sendiri dan lingkungan sekitarnya. Dengan Emotional Quotient (EQ) ini guru akan mampu melakukan praktek-praktek kerja secara berkeunggulan.

Selain kecerdasan emosi sangat diperlukan dalam pekerjaan pendidikan, kecerdasan emosi juga sangat diperlukan dalam berkomunikasi dengan peserta didik karena pada dasarnya dalam pekerjaan pendidikan komunikasi adalah hal yang sangat penting. Dengan kecerdasan emosi, komunikator (guru) akan dapat menggunakan emosinya dengan baik sehingga para guru dalam berkomunikasi dengan benar dan dapat tepat sesuai dengan suasana hati yang diperlukan anak didik dan pihak-pihak yang bekerja sama dalam lingkungan pendidikan di sekolah sehingga hubungan atau kerja sama antar guru-anak didik, guru-atasan di sekolah atau antara guru-orang tua siswa dapat terjalin dengan baik, karena pada hakekatnya komunikasi para guru merupakan proses yang tidak dapat dipisahkan dari keberhasilan kerja-kerja pendidikan yang menjadi tanggung jawab guru tersebut.

Seorang guru yang memiliki kecerdasan emosional yang tinggi, adalah guru yang mampu menunjukkan sikap empati baik pada sesama guru maupun pada siswa lain, memiliki kesadaran diri, memiliki proses pengaturan diri yang baik, memiliki motivasi yang tinggi, memiliki keterampilan dalam bersosialisasi dengan lingkungan sekitarnya, mampu mengendalikan stress, memiliki kemampuan untuk mandiri dan menunjukkan aktualisasi diri serta memiliki tingkat fleksibilitas yang baik dalam pemecahan masalah diduga akan menunjukkan kinerja yang maksimal.

Sikap empati pada guru lain maupun siswa, serta kemampuan bersosialisai yang baik akan membuat guru tersebut mampu beradaptasi dengan lingkungan pekerjaan secara cepat. Proses pengaturan diri yang baik, motivasi yang tinggi, tingkat pengendalian stress yang baik akan membuat guru tersebut menunjukkan kualitas dan ketepatan kerja yang optimal. Selain itu, kemampuan untuk mandiri dan beraktualisasi diri serta tingkat fleksibilitas yang baik dalam pemecahan masalah sangat membantu guru tersebut dalam menemukan gagasan baru.

Jadi seorang guru yang memiliki kecerdasan emosional yang tinggi maka ia mempunyai kinerja yang optimal. Sedangkan seorang guru yang mempunyai kecerdasan emosional yang rendah kinerja yang ditampilkannya diasumsikan tidak akan optimal. Dengan demikian diduga terdapat hubungan positif antara kecerdasan emosional dengan kinerja guru MTs. At Taqwa Kota Tangerang.

\section{METODE PENELITIAN}

Penelitian ini menggunakan pendekatan kuantitatif, dengan metode korelasional. Variabel pertama dalam penelitian ini adalah kecerdasan emosional, yaitu kesadaran diri terhadap emosi yang dihadapi dan mampu untuk mengelola emosi baik yang menyenangkan maupun yang tidak menyenangkan berdasarkan pengalaman masa lalunya, sehingga individu dapat membuat suatu keputusan untuk menampilkan tingkah laku yang sesuai dengan kepentingan yang akan diraihnya (Goleman, 1998). Variabel kedua dalam penelitian ini adalah kinerja guru, yaitu kemampuan dan motivasi kerja yang dimiliki seorang guru dalam kegiatan merencanakan, melaksanakan, dan menilai proses belajar mengajar. Variabel ini ditunjukkan melalui nilai-nilai dari kuesioner yang mengukur aspek-aspek kinerja menurut Mitchell (1989) yaitu: quality of work (kualitas hasil kerja), promptness (ketepatan waktu menyelesaikan pekerjaan), initiative (prakarsa dalam menyelesaikan pekerjaan), capability (kemampuan menyelesaikan pekerjaan) serta $\mathrm{co}$ munication (kemampuan membina kerjasama dengan pihak lain).

Populasi dalam penelitian ini adalah seluruh dewan guru MTs At Taqwa Kota Tangerang yang berjumlah 40 orang. Karena jumlah populasinya dianggap sedikit, maka semua subjek dalam populasi akan menjadi sample penelitian (Arikunto, 1998). Untuk menguji kualitas hubungan variabel digunakan formula Rank Spearman.

\section{HASIL DAN PEMBAHASAN}

\section{Hasil}

Berdasarkan hasil analisis diketahui bahwa koefisien korelasi antara antara kecerdasan emosional dengan kinerja guru adalah sebesar 0,648 dengan $\mathrm{Pv}$ sebesar 0,000 pada taraf signifikansi $\alpha=0,01$ dengan arah pengujian dua sisi. Indeks korelasi sebesar 0,648 tersebut memiliki arti tingkat korelasi sedang. 
Hasil pengujian tersebut, memiliki arti bahwa guru-guru yang memiliki tingkat kecerdasan emosional yang tinggi, umumnya juga memiliki kinerja yang optimal. Sebaliknya, guru-guru yang memiliki tingkat kecerdasan emosional yang rendah, umumnya juga memiliki kinerja yang tidak optimal.

Hasil terebut didukung oleh hasil analisis deskriptif yang menunjukkan bahwa dari $52.5 \%$ guru yang memiliki tingkat kecerdasan emosional yang tinggi, sebanyak 40\% (16 orang) menunjukkan kinerja yang optimal dan $12.5 \%$ (9 orang) lainnya menunjukkan kinerja yang tidak optimal. Hal tersebut memiliki arti, sebagian besar guru yang memiliki tingkat kecerdasan emosional yang tinggi mampu menunjukkan kinerja yang optimal, dan hanya sebagian kecil yang menunjukkan kinerja yang tidak optimal.

Selanjutnya, dari $47.5 \%$ guru yang memiliki tingkat kecerdasan emosional yang rendah, sebanyak 30\% (12 orang) menunjukkan kinerja yang tidak optimal dan $17.5 \%$ (7 orang) lainnya menunjukkan kinerja yang optimal. Hal tersebut memiliki arti, sebagian besar guru yang memiliki tingkat kecerdasan emosional yang rendah menunjukkan kinerja yang tidak optimal, dan hanya sebagian kecil yang menunjukkan kinerja yang optimal.

\section{Pembahasan}

Berdasarkan hasil analisis deskriptif diketahui bahwa sebagian besar $(52.5 \%)$ dewan guru di MTs At Taqwa Kota Tangerang memiliki tingkat kecerdasan emosional yang tinggi, disisi lain sebagian besar guru (57.5\%) juga mampu menunjukkan kinerja yang optimal. Hasil tersebut menunjukkan bahwa memang terdapat hubungan antara kecerdasan emosional dengan kinerja yang ditunjukkan oleh guru di MTs At Taqwa Kota Tangerang.

Data tersebut ditunjang oleh hasil pengujian hipotesis yang telah dilakukan, yaitu diketahui bahwa terdapat hubungan yang cukup signifikan antara kecerdasan emosional dengan kinerja guru MTs At Taqwa Kota Tangerang. Dari analisis deskriptif diketahui bahwa sebagian besar (40\%) guru yang memiliki tingkat kecerdasan emosional yang tinggi mampu menunjukkan kinerja yang optimal. Demikian pula sebaliknya, sebagian besar (30\%) guru yang memiliki tingkat kecerdasan emosional yang rendah menunjukkan kinerja yang tidak optimal.

Hasil penelitian ini mendukung pernyataan Bar-On (dalam Stein, 2000: 4) bahwa kecerdasan emosional merupakan suatu serangkaian kemampuan, kompetensi, dan kecakapan non kognitif yang mempengaruhi seseorang untuk mengatasi tuntutan dan tekanan lingkungan. Dalam kasus penelitian ini tekanan dan tuntutan dari lingkungan yang terjadi adalah tekanan dan tuntutan dari berbagai pihak yang ada di sekitar guru, seperti misalnya ketua yayasan, kepala sekolah, sesam guru, orang tua siswa dan siswa. Guru yang memiliki tingkat kecerdasan emosional yang tinggi akan mampu menghadapi semua tekanan dan tuntutan yang ada, serta tetap mampu menunjukkan kinerja yang optimal.

Menurut Subroto (1997: 3), yang dimaksud dengan kinerja guru dalam proses belajar mengajar adalah kesanggupan atau kecakapan para guru dalam menciptakan suasana komunikasi yang edukatif antara guru dan peserta didik yang mencakup suasana kognitif, afektif dan psikomotorik sebagai upaya mempelajari sesuatu berdasarkan perencanaan sampai dengan tahap evaluasi dan tindak lanjut agar mencapai tujuan pengajaran. Dengan demikian, dari hasil penelitian diketauhi bahwa semakin tinggi tingkat kecerdasan emosional yang dimiliki oleh seorang guru, maka tingkat kesanggupan dan kecakapan para guru pun akan semakin optimal.

Menurut Suharsono (2004:97), ketika berbicara mengenai urgensitas kecerdasan emosional yang dimiliki seseorang dalam kehidupan, terdapat beberapa keuntungan kecerdasan emosional diantaranya; pertama, kecerdasan emosional jelas mampu menjadi alat untuk pengendalian diri, sehingga seseorang tidak terjerumus ke dalam tindakan-tindakan yang merugikan dirinya sendiri maupun orang lain. Kedua, kecerdasan emosional bisa diimplementasikan sebagai cara yang sangat baik untuk memasarkan atau membesarkan ide, konsep atau bahkan sebuah produk. Ketiga, kecerdasan emosional adalah modal penting bagi seseorang untuk mengembangkan bakat kepemimpinan dalam bidang apa pun. Karena setiap model kepemimpinan sesungguhnya membutuhkan visi, misi, konsep, program dan yang tak kalah pentingnya adalah dukungan dan partisipasi dari para anggota. 
Dalam dunia kerja, kinerja yang optimal merupakan suatu keharusan bagi siapapun termasuk guru. Terlebih adanya harapan dari pihak pimpinan untuk mendapatkan pegawai terbaik, adanya persaingan dengan sekolah lain serta siswa yang makin kritis karena derasnya arus informasi baru dari dunia luar. Guru yang cerdas secara emosional akan mampu menghadapi berbagai tutntutan serta tekanan dari lingkungan tersebut dengan menunjukkan kinerja yang tetap optimal.

Seorang guru yang memiliki kecerdasan emosional yang tinggi akan mampu menunjukkan sikap empati baik pada sesama guru maupun pada siswa lain, memiliki kesadaran diri, memiliki proses pengaturan diri yang baik, memiliki motivasi yang tinggi, memiliki keterampilan dalam bersosialisasi dengan lingkungan sekitarnya, mampu mengendalikan stress, memiliki kemampuan untuk mandiri dan menunjukkan aktualisasi diri serta memiliki tingkat fleksibilitas yang baik dalam pemecahan masalah.

Sikap empati pada guru lain maupun siswa, serta kemampuan bersosialisai yang baik akan membuat guru tersebut mampu beradaptasi dengan lingkungan pekerjaan secara cepat. Proses pengaturan diri yang baik, motivasi yang tinggi, tingkat pengendalian stress yang baik akan membuat guru tersebut menunjukkan kualitas dan ketepatan kerja yang optimal. Selain itu, kemampuan untuk mandiri dan beraktualisasi diri serta tingkat fleksibilitas yang baik dalam pemecahan masalah sangat membantu guru tersebut dalam menemukan gagasan baru dalam menjalankan proses belajar mengajar sehingga materi yang disampaikan dapat diterima dengan baik oleh semua siswa.

Terdapat hal menarik dari data deskriptif yang dijelaskan sebelumnya, yaitu terdapat sebagian $(12.5 \%)$ guru yang memiliki tingkat kecerdasan emosional yang tinggi namun menunjukkan kinerja yang tidak optimal. Begitu pula sebagian $(17.5 \%)$ guru yang memiliki tingkat kecerdasan emosional yang rendah namun mampu menunjukkan kinerja yang optimal.

Menurut Simanjuntak (2005: 10-13) hal tersebut dapat terjadi, karena kinerja setiap orang dipengaruhi oleh banyak faktor, diantaranya:

Kompetensi individu. Guru yang memiliki tingkat kecerdasan emosional yang tinggi akan tetapi tidak memiliki kemampuan dan keterampilan kerja yang baik serta memiliki motivasi dan etos kerja yang rendah sudah dapat dipastikan tidak akan menunjukkan kinerja yang optimal. Sebaliknya guru yang memiliki tingkat kecerdasan emosional yang rendah akan tetapi memiliki kemampuan dan keterampilan kerja yang baik serta memiliki motivasi dan etos kerja yang tinggi sudah dapat dipastikan akan menunjukkan kinerja yang optimal.

Dukungan organisasi. Kinerja setiap orang juga tergantung pada dukungan organisasi dalam bentuk pengorganisasian, penyediaan sarana dan prasaran kerja, pemilihan teknologi, kenyamanan lingkungan kerja, serta kondisi dan syarat kerja. Jika sebagian besar dari persyaratan tersebut tidak dapat terpenuhi maka kinerja dari guru pun tidak akan optimal meskipun secara pribadi ia memiliki tingkat kecerdasan emosional yang tinggi.

Dukungan manajemen. Kinerja setiap orang sangat tergantung pada kemampuan manajerial para manajemen atau pimpinan, baik dengan membangun sistem kerja dan hubungan industrial yang aman dan harmonis, maupun dengan mengembangkan kompetensi pekerja, demikian juga dengan menumbuhkan motivasi dan memobilisasi pegawai untuk bekerja secara optimal.

\section{SIMPULAN DAN SARAN}

\section{Simpulan}

Berdasarkan hasil analisis dan pembahasan tentang hubungan antara kecerdasan emosional dengan kinerja guru MTs At Taqwa Kota Tangerang dapat ditarik simpulan bahwa terdapat hubungan positif yang signifikan antara kecerdasan emosional dengan kinerja pada dewan guru di MTs At Taqwa Kota Tangerang. Hasil pengujian tersebut, memiliki arti bahwa guru-guru yang memiliki tingkat kecerdasan emosional yang tinggi, umumnya juga memiliki kinerja yang optimal. Sebaliknya, guru-guru yang memiliki tingkat kecerdasan emosional yang rendah, umumnya juga memiliki kinerja yang tidak optimal.

\section{Saran}

Dengan memperhatikan segala keterbatasan penelitian ini, peneliti mengajukan saran kepada beberapa pihak, diantaranya adalah: 
Pihak sekolah. Supaya guru mampu menunjukkan kinerja yang optimal, pihak sekolah diharapkan mempertahankan pendidikan serta pelatihan yang sudah diberikan pada pihak guru serta menjaga kontinuitas dari pendidikan serta pelatihan tersebut. Selain dengan memberikan pendidikan dan pelatihan, upaya peningkatan kinerja guru juga dapat dilakukan dengan memberikan motivasi pada semua guru, merealisasikan ide-ide positif yang dimiliki guru serta memberikan kompensasi yang positif terhadap guru yang mampu menunjukkan kinerja yang optimal.

Pihak dewan guru. Mengingat pentingnya peran kecerdasan emosional terhadap kinerja guru, maka disarankan kepada dewan guru di MTs At Taqwa Kota Tangerang agar dapat meningkatkan kecerdasan emosionalnya supaya mereka mampu meningkatkan kinerjanya. Cara-cara meningkatkan kecerdasan emosional antar lain, membuka hati dalam arti mau membuka diri untuk menerima suara hati sendiri, mau menerima tanggung jawab, dan mampu menjadi teladan.

\section{DAFTAR PUSTAKA}

Agustian, A. 2001. Emotional Spiritual Quotient. Jakarta: Arga.

Ahiri, J, 2003, Validitas dan Reabilitas Tes: Deskripsi Konsep dan Aplikasinya dalam Evaluasi Pendidikan, Jakarta: Depdiknas Pusat Teknologi Komunikasi dan Informasi Pendidikan.

Aldag, Roman J., and Stearns, Timothy., 1987, Management, Chicago: South Western Publishing Co.

Arikunto, S, 2003, Dasar-dasar Evaluasi Pendidikan, Jakarta : Bumi Aksara.

Azwar, S, 2004. Penyusunan Skala Psikologi. Yogyakarta: Pustaka Pelajar.

Dalyono, M., 1997, Psikologi Pendidikan, Jakarta: Rineka Cipta.

Goleman, D., 2000, Emotional Intelligence, Jakarta: Gramedia Pustaka Utama.

Gsianturi, 2005, Jabatan Tinggi, EQ Rendah?, http://www.kompas.co.id/,

Hartati, N, et.al., 2004, Islam dan Psikologi, Jakarta: Raja Grafindo Persada,

Ibda, F. 2000, Emotional Intellegence dalam Dunia Pendidikan. Banda Aceh: Fakultas Tarbiyah, IAIN Ar-Raniry, Jurnal Didaktika.
J.L., Gibson., dan Cevich, Ivan., 1993, Organisasi dan Manajemen. Jakarta: Erlangga

K. Cooper, Robert., dan Sawaf, Ayman., 2002, Executive EQ. Jakarta: Gramedia

Kountur, R., 2003, Metode Penelitian untuk Penulisan Skripsi dan Tesis, Jakarta: Penerbit PPM.

Lembaga Kajian Pendidikan Keislaman dan Sosial (LeKDiS), 2005. Standar Nasional Pendidikan. Ciputat: Han.s Print.

Mangkunegara, A.A. Anwar Prabu., 2004, Manajemen Sumber Daya Manusia Perusahaan. Bandung: Rosdakarya.

Munandir, 2001, Ensiklopedia Pendidikan, Malang: Um Press.

Najati, U. 1997. Al Qur'an dan Ilmu Jiwa. Bandung: Pustaka.

Nawawi, H., 1996, Administrasi Pendidikan, Jakarta: PT. Gunung Agung,

1985, Organisasi Sekolah dan Pengelolaan Kelas, Jakarta: PT. Gunung Agung,

Nggermanto, A, 2002, Quantum Quotient. Bandung: Nuansa

Nitisemoto, A. S., 1996, Manajemen Personalia. Jakarta: Ghalia Indonesia.

Nurdin, S., dan Usman, M. B, 2002, Guru Profesional dan Implementasi Kurikulum Jakarta: Ciputat Press.

Poerbakawatja, R. S., 1990, Ensiklopedia Pendidikan. Jakarta: Gunung Agung.

Poerwadarminta, WJS., 1988, Kamus Besar Bahasa Indonesia. Jakarta: Departemen Pendidikan dan Kebudayaan.

Pusat Pengembangan Tasawuf Positif, 2002, Menyinari Relung-relung Ruhani, Jakarta: Hikmah..

Rahmat, J dkk. 2002. Menyinari Relung-Relung Ruhani. Jakarta: Iman

Rose, C, dan J. Nicholl, Malcom., 2002, Cara Belajar Cepat Abad XXI. Bandung: Nuansa.

Rusyan, T, dkk, 1994, Pendekatan dalam Proses Belajar Mengajar, Bandung: Rosda

Sabri, M. A, 1996. Psikologi Pendidikan, Jakarta: Pedoman Ilmu Jaya.

--------, 2001. Pengantar Psikologi Umum dan Perkembangan, Jakarta: Pedoman Ilmu Jaya

Segal, J., 2000, Melejitkan Kepekaan Emosional, Bandung: Kaifa

Semiawan, C. R., 2002. Belajar dan Pembelajaran dalam Taraf Pendidikan Usia Dini Jakarta: Prenhallindo. 
Setiadi, A.V. Aryaguna. 2001, Hubungan antara Kecerdasan Emosional dengan Keberhasilan Bermain Game. Surabaya: Universitas Surabaya, Anima, Indonesia Psychological Journal.

Shaleh, A. R., dan Wahab, M. A., 2004. Psikologi Suatu Pengantar dalam Perspektif Islam. Jakarta: Kencana.

Shapiro, L. E, 1998. Mengajarkan Emotional Intellegence pada Anak. Jakarta: Gramedia Pustaka Utama.

Simanjuntak, P. J., 2005. Manajemen dan Evaluasi Kinerja. Jakarta: LPFE UI.

Stein, S. J. \& Book, H. E., 2002. Ledakan EQ. Bandung: Kaifa.

Subroto, S, 1997. Proses Belajar Mengajar. Jakarta: Rineka Cipta.

Sudijono, A, 2004. Pengantar Statistik Pendidikan. Jakarta: PT. Raja Grafindo

Sudjana, 1996. Metoda Statistik. Bandung: Tarsito

Suharsono, 2004, Akselerasi Intelegensi; Optimalkan IQ, EQ dan $S Q$. Depok: Inisiasi Press
2003. Mencerdaskan Anak. Depok: Inisiasi Press

Suprihanto, J, 1997. Manajemen Sumber Daya Manusia II. Jakarta: Karunika UT.

Usman, M. U, 2006. Menjadi Guru Profesional. Bandung: PT. Remaja Rosdakarya

UUSPN, 2003. Undang-undang Republik Indonesia No. 20 Tahun 2003. Bandung: Citra Umbara.

Wahyono, T, 2001. Memahami Kecerdasan Emosi Melalui Kerja Sistem Limbik. Surabaya: Universitas Wangsa Manggala, Anima, Indonesian Psychological Journal

Wijaya, C., dan Rusyana, A. T, 2000. Kemampuan Dasar Guru dalam Proses Belajar Mengajar. Bandung: Remaja Rosda Karya.

Yafie, 2002. Beragama Secara Praktis Agar Hidup Lebih Bermakna. Jakarta: Hikmah

Yusuf, S, 2004. Psikologi Perkembangan Anak dan Remaja. Bandung: Rosdakarya. 